\title{
ANALISIS KEMAMPUAN BERPIKIR REFLEKTIF DAN DISPOSISIMATEMATIS SIWA DITINJAU DARI GAYA BELAJAR
}

\author{
Sofi Amaliyah ${ }^{1}$, Zainul Munawwir ${ }^{2}$, Yesi \\ Puspitasari ${ }^{31,2,3}$ STKIP PGRI Situbondo, Indonesia \\ Email: sofiamaliyah488@ gmai.com
}

\begin{abstract}
ABSTRAK
Penelitian ini bertujuan untuk mendeskripsikan kemampuan berpikir reflektif dan disposisi matematis siswa yang ditinjau dari gaya belajar. Gaya belajar yang dimaksud terdiri dari 3 jenis, yaitu gaya belajar auditori, visual dan kinestetik. Penelitian ini merupakan penelitian deskriptif kualitatif. Subjek dalam penelitian ini adalah siswa kelas XI MA Sarji Ar-Rasyid sebanyak 6 siswa dengan kategori 2 siswa bergaya belajar auditori, 2 siswa bergaya belajar visual dan 2 siswa bergaya belajar kinestetik. Pengumpulan data dalam penelitian ini menggunakan 4 metode yaitu; angket gaya belajar, tes kemampuan berpikir reflektif, angket disposisi matematis dan wawancara kemudian dianalisis pada masing-masing metode pengumpulan data. Hasil penelitian menunjukkan bahwa siswa auditori yang memiliki kemampuan berpikir reflektif tinggi memiliki kriteria tingkat disposisi matematis yang sedang, sedangkan siswa auditori yang memiliki kemampuan berpikir reflektif sedang memiliki kriteria tingkat diposisi matematis yang tinggi. Siswa visual yang memiliki kemampuan berpikir reflektif sedang memiliki kriteria tingkat disposisi matematis yang sedang, siswa visual yang memiliki kemampuan berpikir reflektif rendah memiliki kriteria tingkat diposisi matematis yang sedang. siswa kinestetik yang memiliki kemampuan berpikir reflektif rendah memiliki kriteria tingkat disposisi matematis yang rendah, sedangkan siswa kinestetik yang memiliki kemampuan berpikir reflektif tinggi memiliki kriteria tingkat diposisi matematis yang sedang. Dapat disimpulkan bahwa kemampuan yang baik tidak menjamin tingkat disposisinya juga akanbaik, begitu pula sebaliknya.
\end{abstract}

Kata kunci: Kemampuan berpikir reflektif, Disposisi matematis, Gaya belajar

\begin{abstract}
This study aims to describe the reflective thinking ability and mathematical disposition of students in terms of learning styles. The learning styles in question consist of 3 types, namely auditory, visual and kinesthetic learning styles. This research is a qualitative descriptive study. The subjects in this study were students of class XI MA SarjiAr-Rasyid as many as 6 students with categories 2 students with auditory learning style, 2 students with visual learning style and 2 students with kinesthetic learning style. Collecting data in this study using 4 methods, namely; learning style questionnaire, reflective thinking ability test, mathematical disposition questionnaire and interviews were then analyzed on each data collection method. The results showed that auditory students who had high reflective thinking ability had criteria for a moderate level of mathematical disposition, while auditory students with moderate reflective thinking abilities had criteria for a high level of mathematical disposition. Visual students who have moderate reflective thinking abilities have criteria for a moderate level of mathematical disposition, visual students who
\end{abstract}


have low reflective thinking abilities have criteria for moderate levels of mathematical positioning. Kinesthetic students who have low reflective thinking abilities have criteria for low levels of mathematical disposition, while kinesthetic students who have high reflective thinking abilities have criteria for moderate levels of mathematical disposition. It can be concluded that good ability does not guarantee that the level of disposition will also be good, and vice versa.

Keywords: Reflective thinking ability, Mathematical disposition, learning style

\section{PENDAHULUAN}

Pendidikan merupakan suatu proses belajar seseorang untuk mendapat perubahan baik dari segi kemampuan berpikir, pemahaman ataupun tingkah laku. Salah satu penentu keberhasilan seseorang dalam belajar adalah berpikir reflektif. Menurut Yenni \& Sukmawati (2019) berpikir reflektif adalah proses berpikir yangberdasarkan sebab dan tujuan.

Berdasarkan pengamatan dan pengalaman peneliti di sekolah, peneliti memilih kemampuan berpikir reflektif untuk dianalisis karena kemampuan berpikir reflektif sangat penting untuk dimiliki setiap peserta didik dalam aktivitas pembelajaran di sekolah. Berpikir reflektif dikategorikan menjadi beberapa komponen yaitu techniques, monitoring, insight, dan conceptualizing (Firdausiaetal.,2020).

Berdasarkan pernyataan di atas, Gaya belajar merupakan cara atau aktivitas seseorang dalam memahami materi pembelajaran, jadi lebih mudah untuk mengamatinya. Keberhasilan seseorang atau siswa dalam menyerap informasi untuk memahami materi pembelajaran atau suatu masalah merupakan salah satu indikator pemecahan masalah sehingga sangat penting juga untuk diteliti. Berdasarkan uraian di atas dan diperkuat dengan fakta yang ada, maka tujuan dalam penelitian ini adalah untuk mendeskripsikan kemampuan berpikir reflektif dandisposisi matematis siswa ditinjau dari gaya belajar.

\section{METODE}

Jenis penelitian ini adalah penelitian deskriptif-kualitatif, artinya penelitianini bertujuan untuk menggambarkan atau mendeskripsikan kejadiankejadian yang menjadi pusat perhatian (bagaimana kemampuan berpikir reflektif dan disposisi matematis siswa yang ditinjau dari gaya belajar setiap individu ) secara kualitatif dan berdasar pada data kualitatif. Penelitian ini 
dilaksanakan di MA Sarji Ar Rasyid yang bertempat di Jl. Sucipto Gg. Graha Bumi Ayu Dawuhan Kabupaten Situbondo.

Sumber data dalam penelitian ini adalah peserta didik kelas XI MA Sarji Ar-Rasyid tahun pelajaran 2020/2021. Namun hanya enam peserta didik yang menjadi subjek penelitian. Subjek yang dipilih berdasarkan tipe gaya belajar, yaitudua subjek gaya belajar auditori, dua subjek gaya belajar visual dan dua subjek gayabelajar kinestetik.

\section{HASIL DAN PEMBAHASAN}

\section{Hasil}

Berdasarkan hasil analisis data angket gaya belajar, diperoleh 2 subjek gaya belajar auditori, 2 subjek gaya belajar visual dan 2 subjek gaya belajar kinestetik. Pemilihan subjek berdasarkan perhitungan hasil jawaban yang paling banyak sesuai dengan indikator tipe gaya belajar auditori, visual dan kinestetik.

Tabel 4.2 Subjek Penelitian

\begin{tabular}{clccc}
\hline \multirow{2}{*}{ No } & \multicolumn{1}{c}{ Nama Siswa } & \multicolumn{3}{c}{ Gaya Belajar } \\
& & Auditori & Visual & Kinestetik \\
\hline 1 & Muhammad yudli Ulhaq & $\mathbf{6}$ & 4 & 0 \\
\hline 2 & Siti Nur Amelia & $\mathbf{6}$ & 3 & 1 \\
\hline 3 & Defi Sriwahyuni & 3 & $\mathbf{6}$ & 1 \\
\hline 4 & Siti Aminah & 3 & $\mathbf{6}$ & 1 \\
\hline
\end{tabular}




\begin{tabular}{clccc}
\hline \multirow{2}{*}{ No } & Nama Siswa & \multicolumn{3}{c}{ Gaya Belajar } \\
& & Auditori & Visual & Kinestetik \\
\hline 5 & Farhan Ainurrohman & 3 & 2 & $\mathbf{5}$ \\
\hline 6 & Luluk Zamratul Aisyah & 3 & 2 & $\mathbf{5}$
\end{tabular}

Dari ke enam subjek yang dipilih, dilakukan tes kemampuan berpikir reflektif lalu di analisis untuk menentukan tingkat kemampuan berpikir reflektif pada masing-masing sujek dengan tipe gaya belajarnya.

Tabel 4.3 Tabel Hasil Tes Kemampuan Berpikir Reflektif Siswa

\begin{tabular}{lcccc}
\hline \multicolumn{1}{c}{ Nama Siswa } & $\begin{array}{c}\text { Tipe } \\
\text { Gaya } \\
\text { Belajar }\end{array}$ & $\begin{array}{c}\text { Nilai } \\
\text { Subjek }\end{array}$ & $\begin{array}{c}\text { Kategori } \\
\text { Kemampuan } \\
\text { Berpikir Reflektif }\end{array}$ & $\begin{array}{c}\text { Kode } \\
\text { Subjek }\end{array}$ \\
\hline Muhammad Yudli Ulhaq & Auditori & 95 & Tinggi & SAT \\
\hline Siti Nur Amelia & Auditori & 85 & Sedang & SAS \\
\hline Defi Sriwahyuni & Visual & 85 & Sedang & SVS \\
\hline Siti Aminah & Visual & 70 & Rendah & SVR \\
\hline Farhan Ainurrohman & Kinestetik & 70 & Rendah & SKR \\
\hline Luluk Zamratul Aisyah & Kinestetik & 98 & Tinggi & SKT
\end{tabular}

Angket tersebut berjumlah 23 pernyataan dengan perhitungan menggunakan skala likert. Berikut adalah kriteria tingkat disposisi matematis siswa dari hasil pengolahan skor angket;

Tabel 4.11 Kriteria Tingkat Disposisi Matematis

\begin{tabular}{lcccc}
\hline \multicolumn{1}{c}{ Nama } & $\begin{array}{c}\text { Tipe } \\
\text { Gaya } \\
\text { Belajar }\end{array}$ & $\begin{array}{c}\text { Skor } \\
\text { Angket }\end{array}$ & $\begin{array}{c}\text { Presentase } \\
(\boldsymbol{\%})\end{array}$ & $\begin{array}{c}\text { Kriteria } \\
\text { Disposisi } \\
\text { Matematis }\end{array}$ \\
\hline Muhammad Yudli Ulhaq & Auditori & 65 & 70,6 & Sedang \\
\hline Siti Nur Amelia & Auditori & 78 & 84,8 & Tinggi \\
\hline Defi Sriwahyuni & Visual & 69 & 75 & Sedang \\
\hline Siti Aminah & Visual & 66 & 71,7 & Sedang \\
\hline Farhan Ainurrohman & Kinestetik & 55 & 59,8 & Rendah \\
\hline Luluk Zamratul Aisyah & Kinestetik & 63 & 68,5 & Sedang \\
\hline
\end{tabular}


Auditori, visual dan kinestetik, dilakukan dengan memberikan angket gaya belajar untuk diisikepada semua siswa kelas XI MA Sarji Ar-Rasyid yang berjumlah 19 siswa. Penentuan subjek berdasarkan perhitungan hasil jawaban yang paling banyak sesuai dengan tipe gaya belajar auditori, visual dan kinestetik. Dari hasil analisis data angket gaya belajar, diperoleh 2 subjek gaya belajar auditori, 2 subjek gaya belajar visual dan 2 subjek gaya belajar kinestetik. Ke enam subjek tersebut, dianalisis kemampuan berpikir reflektif dan disposisi matematisnya.

\section{Kemampuan Berpikir Reflektif Ditinjau dari Gaya Belajar}

a. Kemampuan Berpikir Reflektif Siswa Auditori

Berdasarkan hasil analisis data yang telah dipaparkan dari hasil tes kemampuan berpikir reflektif dan hasil wawancara pergaya belajar, menunjukkan bahwa kemampuan SAT dalam memahami permasalahan pada soal sudah baik. Hal ini dapat dilihat saat SAT menyelesaikan soal dengan lancar menuliskan informasi apa saja yang ada dalam soal. Hal tersebutmembuktikan bahwa SAT sudah percaya diri dalam menuliskan informasi yang didapatnya. Pernyataan tersebut juga diperkuat ketika proses wawancara belangsung, SAT dengan penuh keyakinan menjawab setiap butir pertanyaan yang ditanyakan peneliti tanpa ada rasa takut.

Selain itu, ketika wawancara berlangsung SAT juga dengan percaya diri menjawab setiap pertanyaan yang ditanyakan peneliti. Hal tersebut membuktikan bahwa tingkat kemampuan berpikir reflektif SAT dalammenyusun rencana untuk memecahkan permasalahan adalah tinggi. Selain itu, SAT juga bisa mempertanggung jawabkan solusi yang dikerjakannya. Hal ini dapat dilihat dari cara SAT menjawab pertanyaan peneliti dengan penuh keyakinan saat wawancara. Selain bisa mempertanggung jawabkan solusinya, SAT juga mengetahui alasan dari solusi yang digunakan untuk memecahkan 
soal. Sehingga siswa SAT dengan mudah menyelesaikan soal.

Sedangkan hasil analisis data tes kemampuan berpikir reflektif siswa auditori sedang (SAS), kemampuan SAS dalam memahami permasalahan pada soal cukup baik. Hal ini dapat dilihat saat SAS menuliskan informasi yang ada dalam soal masih ada kekurangan yaitu titik koordinat $\mathrm{O}, \mathrm{A}, \mathrm{B}$ dan $\mathrm{C}$ tidak disebutkan. Hal tersebut membuktikan bahwa SAS sudah percaya diri dalam menuliskan informasi yang didapat namun kurang teliti dalam memahami pertanyaan pada soal. Pernyataan tersebut juga diperkuat ketika proses wawancara belangsung, SAS dengan yakin menjawab setiap butir pertanyaan yang ditanyakan peneliti tapi kurang lengkap.

\section{PEMBAHASAN}

Penentuan subjek penelitian berdasarkan tipe gaya belajar yakni peneliti tentang jawaban soal yang telah dikerjakannya masih ada kekurangan terutama ketika wawancara disuruh menjelaskan langkah penyelesaian soal. Hal tersebut membuktikan bahwa tingkat kemampuan berpikir reflektif SVS dalam menyusun rencana untuk memecahkan permasalahan adalah sedang. Meskipun jawaban SVS masih terdapat kekurangan, SVS masih bisa mempertanggung jawabkan solusi jawaban soal yang dikerjakan dan SVS juga bisa memberikan alasan solusi yang digunakan untuk menyelesaikan soal yaitu rasa yakin terhadap dirinya dengan apa yang sudah dikerjakannya.

Sedangkan hasil analisis tes kemampuan berpikir reflektif siswa visual rendah (SVR), menunjukkan bahwa kemampuan SVR dalam memahami permasalahan pada soal kurang baik. Hal ini dapat dilihat saat SVR menyelesaikan soal, SVR berpikir dengan waktu yang cukup lama menuliskan informasi yang ada dalam soal. Hal tersebut membuktikan bahwa SVR kurang percaya diri dalam menuliskan informasi yang didapatnya. Pernyataan tersebutjuga diperkuat ketika proses wawancara belangsung, SVR dengan singkat menjawab setiap butir pertanyaan yang ditanyakan peneliti. 
Dalam penyusunan rencana penyelesaian, keyakinan SVR untuk menyelesaikan soal kurang. Hal ini ditunjukkan ketika SVR menuliskan penyusunan rencana yang diambilnya untuk memecahkan permasalahanan yang terdapat dalam soal dengan ragu ragu. Pernyataan tersebut juga diperkuat ketika wawancara berlangsung, cara SVR menjawab pertanyataan peneliti sangat singkat . Hal tersebut membuktikan bahwa tingkat kemampuan berpikirreflektif SVR dalam menyusun rencana untuk memecahkan permasalahan tergolong rendah. Cara penyelesaian masalah yang dilakukan oleh SVR berbeda dengan subjek penelitian dari Wulansari (2020) yang menyelesaikan masalah dengan baik, hal tersebut dilihat dari pemehaman masalah dan rencanapenyelesaian yang baik, serta subjek tersebut memahami dengan baik langkah yang dia pakai, sehingga dalam wawancaranya subjek tersebut dengan yakin menjelaskan hasil penyelesaiannya dengan baik. Seperti halnya SVS menyelesaikan masalah dengan cukup baik. Berbeda dengan SVR pada saat wawancara masih kurang dalam memahami penyelesaian masalah yang dia kerjakan sendiri.

Selain itu, SVR juga tidak bisa mempertanggung jawabkan solusi yangdigunakan. Hal tersebut dibuktikan dari hasil wawancara, SVR yakin dengan jawabannya namun SVR tidak menyertakan alasan dari solusinya. Dari jawaban tersebut membuktikan bahwa SVR juga tidak mengetahui alasan dari solusi yang digunakan untuk memecahkan masalah yang ada dalam soal karenaSVR hanya bisa menyelesaikan soal namun tidak bisa menjelaskan ketika dilakukan wawancara. Hal itu juga yang menyebabkan kemampuan berpikir reflektif SVR tergolong rendah.

\section{a. Kemampuan Berpikir Reflektif Siswa Kinestetik}

Berdasarkan hasil analisis data yang telah dipaparkan dari hasil tes kemampuan berpikir reflektif dan hasil wawancara pergaya belajar, menunjukkan bahwa kemampuan SKR dalam memahami permasalahan soal kurang baik. Hal ini dapat dilihat saat SKR menyelesaikan soal, SKR sering mengecek kembali jawaban yang ditulis dan mencocokkannya dengan pertanyaan yang ada dalam soal. Hal tersebut membuktikan bahwa SKR kurang percaya diri dalam menuliskan informasi yang 
didapatnya. Pernyataan tersebut juga diperkuat ketika proses wawancara belangsung, SKR dengan singkat menjawab setiap butir pertanyaan yang ditanyakan peneliti. Dalam penyusunan rencana penyelesaian, keyakinan SKR untuk menyelesaikan soal kurang. Hal ini ditunjukkan ketika SKR menuliskan penyusunan rencana untuk memecahkan permasalahanan yang terdapat dalam soal dengan ragu ragu. Pernyataan tersebut juga diperkuat ketika wawancara berlangsung, cara SKR menjawab pertanyataan peneliti sangat singkat .

Siswa kinestetik skor 63 dengan persentase 68,5\% menunjukkan bahwa kriteria tingkat disposisi matematisnya tergolong sedang. Siswa kinestetik yang memiliki disposisi matematis sedang, memiliki kepercayaan diri yang cukup baik yaitu yakin dan berusaha menjawab soal yang diberikan namun masih ada keragu-raguan; senang mengerjakan soal yang berbentuk soal cerita ataupun yang lainnya dengan cara yang bervariasi; mudah putus asa tapi tidak malu bertanya apabila ada materi yang kurang dimengerti serta senang mengerjakan soal-soal latihan untuk memperdalam pemahaman; memiliki persiapan sebelum memulai pembelajaran seperti membaca materi dan mencari referensi lain; tidak senang mengulang kembali pelajaran yang telah dipelajari; mengetahui peran matematika berkaitan dengan kehidupan sehari-hari dan displin ilmu lain. Selain itu juga mengetahui bahwa kesuksesan pada mata pelajaran matematika dapat mendukung kesuksesan pada mata pelajaran lain.

\section{Disposisi Matematis Siswa Ditinjau dari Gaya Belajar}

Disposisi Matematis Siswa Auditori

Berdasarkan hasil analisis data yang telah dipaparkan dari hasil angket disposisi matematis siswa dan hasil wawancara, siswa auditori skor 65 dengan persentase 70,6\% menunjukkan bahwa kriteria tingkat diposisi matematisnya tergolong sedang. Siswa auditori yang memiliki disposisi matematis sedang, memiliki kepercayaan diri yang cukup baik yaitu yakin dan berusaha menjawab/menyelesaikan soal yang diberikan; senang mengerjakan soal yang berbentuk soal cerita ataupun yang lainnya dengan cara yang bervariasi; tidak malu 
bertanya apabila ada materi yang kurang dimengerti serta senang mengerjakan soalsoal latihan untuk memperdalam pemahaman; memiliki persiapan sebelum memulai pembelajaran seperti membaca materi dan mencarireferensi lain; mengulang kembali pelajaran yang telah dipelajari serta mengaitkan materi yang baru dengan materi yang sudah dipelajari; belum sepenuhnya mengetahui peran matematika berkaitan dengan kehidupan sehari-hari dan displin ilmu lain. Selain itu, juga tidak mengetahui bahwa kesuksesan pada mata pelajaran matematika dapat mendukung kesuksesan pada mata pelajaran lain.

Siswa auditori skor 78 dengan persentase 84,8\% menunjukkan bahwa kriteria tingkat disposisi matematisnya tergolong tinggi. Siswa auditori yang memiliki disposisi matematis tinggi, memiliki kepercayaan diri yang tinggi yaitu yakin dan berusaha menyelesaikan soal yang diberikan; senang mengerjakan soal yang berbentuk soal cerita ataupun yang lainnya dengan carayang bervariasi; tidak mudah putus asa dan suka bertanya apabila ada materi yang kurang dimengerti serta senang mengerjakan soal-soal latihan untuk memperdalam pemahaman; memiliki persiapan sebelum memulai pembelajaran seperti membaca materi dan mencari referensi lain; cenderung mengulang kembali pelajaran yang telah dipelajari serta mengaitkan materi yang baru dengan materi yang sudah dipelajari; mengetahui peran matematika berkaitan dengan kehidupan sehari-hari dan disiplin ilmu lain; selain itu juga mengetahui bahwa kesuksesan pada mata pelajaran matematika dapat mendukung kesuksesan pada mata pelajaran lain.

b. Disposisi Matematis Siswa Visual

Berdasarkan hasil analisis data yang telah dipaparkan dari hasil angket disposisi matematis siswa dan hasil wawancara, siswa visual skor 69 dengan persentasi $75 \%$ menunjukkan bahwa kriteria tingkat diposisi matematisnya tergolong sedang. Siswa visual yang memiliki disposisi matematis sedang, memiliki kepercayaan diri yang cukup baik yaitu rasa yakin dalam menjawab/menyelesaikan soal yang diberikan masih ada keragu-raguan; senang mengerjakan soal yang berbentuk soal cerita ataupun yang lainnya namun cukup dengan satu cara saja; tidak mudah putus asa dan tidak malu bertanya apabila ada materi yang kurang dimengerti serta senang mengerjakan soal-soal latihan untuk 
memperdalam pemahaman; memiliki persiapan sebelum memulai pembelajaran seperti membaca materi dan mencari referensi lain; senang mengulang kembali pelajaran yang telah dipelajari serta mengaitkan materi yang baru dengan materi yang sudah dipelajari; mengetahui peran matematika berkaitan dengan kehidupan sehari-hari dan displin ilmu lain; serta mengetahui bahwa kesuksesan pada mata pelajaran matematika dapat mendukung kesuksesan pada mata pelajaran lain.

Siswa visual skor 66 dengan persentase $71,7 \%$ menunjukkan bahwa kriteria tingkat disposisi matematisnya juga tergolong sedang. Siswa visual yang memiliki disposisi matematis sedang, memiliki kepercayaan diri yang cukup baik yaitu masih ada rasa ragu dalam menjawab/menyelesaikan soal yang diberikan; senang mengerjakan soal yang berbentuk soal cerita ataupun yang lainnya dengan cara yang bervariasi; tidak mudah putus asa dan tidak malu bertanya apabila ada materi yang kurang dimengerti serta senang mengerjakan soal-soal latihan untuk memperdalam pemahaman; memiliki persiapan sebelum memulai pembelajaran seperti membaca materi dan mencari referensi lain; tidak suka mengulang kembali pelajaran yang telah dipelajari; mengetahui peran matematika berkaitan dengan kehidupan sehari-hari dan displin ilmu lain; serta mengetahui bahwa kesuksesan pada mata pelajaran matematika dapat mendukung kesuksesan pada mata pelajaran lain.

Dalam penelitian yang dilakukan oleh (Haryati et al., 2017) hasil penelitiannya berbeda dengan hasil penelitian ini, hasil penelitian yang dilakukan peneliti terdahulu menyatakan bahwa hasil disposisi berpikir reflektif dari ketiga gaya belajar adalah kuat, tetapi jika dibandingkan berdasarkan presentase disposisinya, gaya belajar visual memiliki hasil paling kuat dari gaya belajar lainnya. Sedangkan dalam penelitian ini, presentase disposisi gaya belajar visual kalah dengan presentase disposisi gaya belajar auditori. Kesimpulannya dalam penelitian ini gaya belajar auditori memiliki disposisi matematis yang lebih tinggi dari gaya belajar lainnya, sehingga berbeda dengan hasil penelitian terdahulu. 


\section{c. Disposisi Matematis Siswa Kinestetik}

Berdasarkan hasil analisis data yang telah dipaparkan dari hasil angket disposisi matematis siswa dan hasil wawancara, siswa auditori skor 55 dengan persentase 59,8\% menunjukkan bahwa kriteria tingkat diposisi matematisnya tergolong rendah. Siswa kinestetik yang memiliki disposisi matematis rendah, memiliki kepercayaan diri yang cukup baik yaitu yakin dan berusaha menjawab soal yang diberikan; senang mengerjakan soal yang berbentuk soalcerita ataupun yang lainnya namun cukup dengan satu cara saja; mudah putus asa dan malu bertanya apabila ada materi yang kurang dimengerti serta kurangsenang mengerjakan soal-soal latihan; tidak memiliki

\section{KESIMPULAN}

Berdasarkan hasil dan pembahasan, dapat disimpulkan bahwa siswa auditori yang memiliki kemampuan berpikir reflektif tinggi memiliki kriteria tingkat disposisi matematis yang sedang, sedangkan siswa auditori yang memiliki kemampuan berpikir reflektif sedang memiliki kriteria tingkat diposisi matematis yang tinggi. Siswa visual yang memiliki kemampuan berpikir reflektif sedang memiliki kriteria tingkat disposisi matematis yang sedang, sedangkan siswa visual yang memiliki kemampuan berpikir reflektif rendah memiliki kriteria tingkat diposisi matematis yang sedang. Siswa kinestetik yang memiliki kemampuanberpikir reflektif rendah memiliki kriteria tingkat disposisi matematis yang rendah, sedangkan siswa kinestetik yang memiliki kemampuan berpikir reflektif tinggi memiliki kriteria tingkat diposisi matematis yang sedang. Dengan demikian, disimpulkan bahwa kemampuan yang baik tidak menjamin tingkat disposisinya juga akan baik, begitu pula sebaliknya. 


\section{DAFTAR PUSTAKA}

Chania, H. \& S. (2020). Hubungan Gaya Belajar dengan Hasil Belajar Siswa padaPembelajaran Biologi Kelas X SMAN 2 Sungai. jxbjx.

Firdausia, S., Shaliha, A., Studi, P., Matematika, P., Keguruan, F., Ilmu, D. A. N., \& Surakarta, U. M. (2020). Memecahkan Masalah Sistem Koordinat persiapan apapun

Matematika FKIP Universitas Muhammadiyah Surakarta ). universitas surakarta.

Haryati, T., Nindiasari, H., \& Sudiana, R. (2017). Analisis Kemampuan Dan Disposisi Berpikir Reflektif Matematis Siswa Ditinjau Dari Gaya Belajar. Jurnal Penelitian Dan Pembelajaran Matematika, 10(2), 146-158. https://doi.org/10.30870/jppm.v10i2.2039

Hidayatulloh. (2015). Pemetaan Tingkat Berpikir Kreatif Mahasiswa Pendidikan Matematika Dalam Pemecahan Masalah Soal Analisis Real 2 Ditinjau. JurnalE-DuMath, 1(2), 97-105.

Jaenudin, J., Nindiasari, H., \& Pamungkas, A. S. (2017). Analisis Kemampuan Berpikir Reflektif Matematis Siswa Ditinjau Dari Gaya Belajar. Prima: $\begin{array}{llll}\text { Jurnal Pendidikan } & \text { Matematika, } & \text { l(1), }\end{array}$ https://doi.org/10.31000/prima.v1i1.256

Lestari, L., Suharto, S., \& Fatahillah, A. (2016). Analisis Pengaruh Disposisi Matematis terhadap Hasil Belajar Materi Integral Tak Tentu Siswa Kelas XII IPA 2 SMAN 4 Jember. Jurnal Edukasi, 3(1), 40. https://doi.org/10.19184/jukasi.v3i1.4320

Mahfuza. (2019). Peningkatan Berpikir Reflektif Siswa Madrasah Ibtidaiyah

Melalui Pendekatan Matematika Realistik. Ayan, 8(2), 2019. https://doi.org/10.22201/fq.18708404e.2004.3.66178

Masamah, U. (2017). Peningkatan Kemampuan Berpikir Reflektif Matematis Siswa SMA melalui Pembelajaran Berbasis Masalah Ditinjau dari Kemampuan Awal Matematika. Jurnal Penelitian Pendidikan Matematika, 1(1), 1-18.

Mastuti, R. A. (2018). Identifikasi Disposisi Matematika Siswa Dalam 
Pembelajaran Socrates Kontekstual Pada Materi Sistem Persamaan Linear Dua Variabel Pada Siswa Kelas Viii Smp. JIPMat, 3(2), 140-144. https://doi.org/10.26877/jipmat.v3i2.2396

Nababan, S. A., \& Tanjung, H. S. (2020). Pengembangan Perangkat Pembelajaran Berbasis Pendekatan Matematika Realistik untuk Meningkatkan Kemampuan Disposisi Matematis Siswa SMA Negeri 4 Wira Bangsa Kabupaten Aceh Barat. Genta Mulia, XI(2), 236. 
Nurdika, S. A. (2019). Pengaruh Disposisi Matematis Terhadap Kemampuan Komunikasi Matematis Siswa Kelas VIII SMP N 1 Paguyangan Kabupaten Brebes Tahun Pelajaran 2018/2019. Institut Agama Islam Negeri Purwokerto. pamungkas, A. S., Mentari, N., \& Nindiasari, H. (2018). Analisis KemampuanBerpikir Reflektif Siswa SMP Berdasarkan Gaya Belajar.

NUMERICAL: Jurnal Matematika Dan Pendidikan
https://doi.org/10.25217/numerical.v2i1.209

Pramesti \& Ratnadi. (2020). Pengaruh Kecerdasan Emosional, Gaya

BelajarVisual, Gaya Belajar Auditorial dan Gaya Belajar

Kinestetikpada TingkatPemahaman Akuntansi. 3(2), 356-369.

https://www.metis2020.com/wp-

content/uploads/METIS_D1.4_v3.pdf\%0Ahttps://www.metis2020.com/d $\mathrm{ocu}$

ments/deliverables/index.html\%0Ahttps://www.metis2020.com/metisdeliverables-d1-4-d2-4-d3-3-d4-3-d6-5-and-d7-3-were-completed-infebruary-2015/index.html\%0Ahttp

Prasetyo, A. (2017). Kemampuan Koneksi dan Disposisi Matematis Siswa Ditinjaudari Tipe Kepribadian Keirsey pada Pembelajaran Matematika Model Eliciting Activities. Unnes Journal of Mathematics Education, 6(2), 190-197. Pratiwi, A. R. (2016). Analisis Kemampuan Pemecahan Masalah BerdasarkanDisposisi Matematis Peserta Didik dalam Setting Model Anchored Instruktion. Universitas Negeri Semarang.

Purbaningrum, K. A. (2017). Kemampuan Berpikir Tingkat Tinggi Siswa Smp Dalam Pemecahan Masalah Matematika Ditinjau Dari Gaya Belajar. Jurnal Penelitian Dan Pembelajaran Matematika, 10(2), 40-49. https://doi.org/10.30870/jppm.v10i2.2029

Putri, A. S., \& Mampouw, H. L. (2018). Profil berpikir reflektif siswa dalam menyelesaikan soal tipe-tipe perkalian ditinjau dari perbedaan kemampuan matematika dan gender. Math Didactic: Jurnal Pendidikan 
Matematika, 4(1),34-46. https://doi.org/10.33654/math.v4i1.81 
Rahayu. (2016). Hubungan Daya Serap dengan Peningkatan Prestasi Belajar Siswa SDN No 01 Centre Pattallassang Kabupaten Takalar. 5(01), 8086.

Rahmalia, Hajidin, \& \& Ansari. (2020). Peningkatan Kemampuan Komunikasi Matematis dan Disposisi Matematis Siswa SMP melalui Model Problem 
Based Learning.

Numeracy,

$7(1)$

$137-$

149.https://doi.org/10.46244/numeracy.v7i1.1038

Sugiyono. (2016). Metode Penelitian (Alfabeta (ed.); Alfabeta). Alfabeta. Suryaprani, M. W., Suparta, I. N., \& Suharta, I. G. P. (2016). Disposisi Matematika

Terhadap Prestasi Belajar. Seminar Nasional MIPA, 39-46.

Tefa, S., Idayani, D., \& Astindari, T. (2019). Perbandingan Hasil Belajar Siswa antara Pemberian Tugas Kelompok dan Tugas Individu pada Mata Pelajaran Matematika di SMP Negeri 6 Situbondo. Edusaintek: Jurnal Pendidikan SainsDan Teknologi, 6(1), 23-33.

Wulansari. (2020). Analisis Kemampuan Berpikir Kreatif Matematis Ditinjau DariSelf-Concept Matematis Siswa. Jurnal Cendekia : Jurnal Pendidikan Matematika, 4(2), 512-525. https://doi.org/10.31004/cendekia.v4i2.244

Yenni, Y., \& Sukmawati, R. (2019). Analisis Kemampuan Berpikir Reflektif Matematis Berdasarkan Minat Belajar Pada Mata Kuliah Struktur Aljabar. Teorema: Teori Dan Riset Matematika, 4(2), 75. https://doi.org/10.25157/teorema.v4i2.2283

Yuliza, S. (2020). Pengaruh Disposisi Matematis terhadap

KemampuanKomunikasi Matematis Siswa Kelas VIISMPMuhammadiyah3 Bandarlampung (Vol. 01, Issue 01). Universitas Lam 
